\title{
APEC: Regionalism, Globalism, or Obfuscation?
}

\author{
George Fane
}

A SIA-PACIFIC ECONOMIC COOPERATION (APEC), which now has 18 members, was set up in 1989 to promote economic cooperation and trade liberalisation. The 1994 Leaders' Meeting resulted in the Bogor Declaration, which announced a commitment to achieving free and open trade in the Asia-Pacific no later than 2020, and by 2010 for the industrialised members of APEC. However, it is argued here that the reluctance of members to make binding commitments, and APEC's consequent lack of adequate powers of enforcement, will largely nullify these attempts to liberalise trade. APEC will therefore probably end up merely as a regional version of the Organisation for Economic Cooperation and Development (OECD). Indeed, the creation of an APEC bureaucracy is well under way: a permanent secretariat and ten working groups have already been established.

It is somewhat surprising that APEC has gained widespread support from national governments, given that its promises of trade liberalisation lack credibility, that the case for an OECD for the Asia-Pacific was rejected in the 1970s, and that even the case for the OECD itself is now being questioned. The explanation suggested here is that APEC's lofty goals and high profile have allowed it to fill the vacuum created by the obsolescence of older summit gatherings, such as the Non-Aligned Movement and the Commonwealth, which likewise provided national leaders with international stages on which to be seen performing statesmanlike actions.

\section{Regionalism vs Globalism}

Despite its bureaucracy and its six years of reports, meetings and declarations, APEC has still not resolved the most basic issue facing it: whether to adopt regionalism, with members offering one another trade preferences, or globalism, with members extending the benefits of trade liberalisations to all countries equally. The Bogor Declaration left this choice open by qualifying 'the goal of free and open trade' by the clause 'in the Asia-Pacific'. 'The Australian Minister for Trade, Senator R. McMullan, was recently reported as saying that APEC might 'never' need to confront the potentially divisive issue of non-discrimination as it moved towards its goal of free trade by 2020 (The Australian, 28 June 1995).

George Fane is Senior Fellow in the Research School of Pacific and Asian Studies at The Australian National University. 
The argument between globalism and regionalism was fought out, but not funally resolved, within the APEC Eminent Persons Group (EPG) during the writing of the EPG's 1994 Report. The case for regionalism, which is supported by the US and Canadian governments, was made by the US Chairman of the EPG, Professor C. Fred Bergsten; globalism, which is supported by the Japanese and Australian governments, was advocated by Australia's EPG representative, Neville Wran. In my view, both options face difficulties that may well be insurmountable; but, since globalism is unenforceable, it will achieve almost nothing, and Australia would therefore have done better to explore the feasibility of regional agreements.

The choice between regionalism and globalism now facing APEC countries can be clarified by an analogy with the trade-policy choices faced a century ago by the six future Australian States. The drafters of the Australian Constitution were right to guarantee the freedom of interstate trade; and, analogously, I believe that APEC countries would gain by removing existing barriers to intra-regional trade. However, whereas I favour free trade between Australia and the rest of the world, I am opposed to the pursuit of globalism by APEC.

There are two main differences between the two cases. First, APEC is large enough to have substantial bargaining power, whereas Australia has always been a very small part of the world economy. It is therefore in APEC's interest to demand reciprocal concessions from the rest of the world rather than to liberalise unilaterally. This argument applies more strongly to the larger countries in APEC than to the smaller ones; but Australia should nevertheless use whatever influence it has to encourage the US and Japan to demand reciprocal trade liberalisations from the rest of the world.

The second difference is far more important. The central purpose of this article is to argue that the supporters of APEC globalism have grossly underestimated the problem of enforcement, and that if APEC tries to adopt globalism enforced by moral suasion it will fail to achieve any significant trade liberalisation. The Australian States achieved freedom of interstate trade by means of the High Court and a guarantee in Section 92 of the Australian Constitution; the APEC analogue would be a detailed, enforceable, regional free-trade agreement. Extending freedom of interstate trade to free trade between Australia and the rest of the world would have required an additional constitutional guarantee. In contrast, if the drafters of Australia's Constitution had implemented the analogue of APEC globalism, they would have inserted the following two provisions in place of the present s.92: a non-binding declaration that all States set a goal of complete free trade in the distant future; and a binding requirement that, in the meantime, each State impose the same tariffs on trade with each other State that it imposes on trade with foreign countries. In terms of the APEC analogy, dispensing with s.92 corresponds to the decision not to have an enforceable regional agreement; the non-binding declaration is the Bogor Declaration; and the binding re-

\footnotetext{
I am grateful to Ted Sieper for pointing out this similarity.
} 
quirements are obligations of APEC countrics to grant most favoured nation (MFN) treatment to all members of the World Trade Organisation (WTO),

The substitution of these two provisions for Australia's constitutional guarantee of freedom of interstate trade would have meant imposing on international trade any tariffs on external trade. Relative to enforceable regionalism, the case against nonbinding globalism is that it would sacrifice limited regional trade liberalisation for an unachievable utopia. If, as now seems likely, it is impossible for Australia to achieve a regional free-trade treaty with even a subset of APEC countries, broader than its existing agreement with New Zealand, then it should stop pretending that APEC is more than a regional version of the OECD.

\section{The Role of Obfuscation}

The drafters of the 1994 EPG Report attempted to paper over the conflict between the regionalist and globalist options proposed by Bergsten and Wran by adopting two obfuscations. The first was to deny making any recommendation that APEC become a free-trade area (FTA) but nevertheless to recommend that it become an organisation meeting the conventional definition of an FTA, as given in Article XXIV.8(b) of the General Agreement on Tariffs and Trade (GATT). Admittedly, the form of the FTA recommended by the Report is more open than that of existing FTAs. The second obfuscation was that, while unambiguously rejecting globalism, the EPG Report nevertheless accepted the label 'open regionalism', which had previously been adopted by the supporters of globalism to describe their own preferred option for APEC.

The label 'open regionalism' is itself a contradiction in terms: if a program of trade liberalisation is 'open', in the sense of not seeking to discriminate against the rest of the world, then it cannot involve 'regionalism' in the established sense of a prefer-

2 The general MFN provision of Article I of GATT may be roughly paraphrased as follows: with respect to customs duties and other similar taxes and regulations applied to the imports or exports of any product, each member must treat trade with each other member in a way which is at least as favourable as that applied to tracle in the same product with any other counuy, 'the most favoured nation'. GATT provides for various exemptions from the general MFN provision of Auticle I. The two most important exemptions are, first, that preferences may be grunted to imports from developing countries; and second, that countries have the right under Article XXIV to set up FTAs or customs unions, in which the members remove barriers on substantially all trade between each other, provided that the formation of the bloc does not raise the average level of tade bariers between members of the bloc and non-members.

The EPG Report makes a persuasive case for rejecting globalism (p.21). Proposals which would constitute an FTA are set out in the EPG's 'four-paut formula' (pp.19-20). There is even a discussion (pp.30-31) of the rules of origin that APEC would need under these regionalist proposals. The Report's extraordinary assertion that it does not recommend the creation of an FTA occurs on page 35, where an attempt is made to justify this assertion by pointing out that, under its proposals, APEC would be more open than an FTA needs to be in order to conlorm with WTO/GATT requirements. With equal validity: 'an open box is not a box, because a box can be closed.' 
ential trade agreement among a subset of nations. The advantage of seeming to offer openness and regionalism simultaneously explains why the term has been used by the advocates of both globalism and regionalism to describe their conflicting recommendations. For APEC globalists, it has the major advantage of obscuring the fact that the trade policy component of their proposals does not involve any regional element at all, while the truly regionalist components of these proposals involve some discrimination against outsiders. For example, it is misleading to suggest that policies such as intergovernment cooperation in the provision of infrastructure can involve regionalism without discriminating against outsiders. If $\mathrm{APEC}$ governments make reciprocal agreements resulting in less strict appraisal criteria being applied to projects which primarily facilitate Asia-Pacific trade than to projects which facilitate trade with all countries, the policy clearly discriminates against outsiders. If the magnitude of this discrimination is negligible, the policy should be called 'negligible regionalism'.

\section{Free-riding and the Need to Enforce Trade Agreements}

The advocates of APEC globalism have paid little attention to the problems of enforcing trade agreements. For example, the Bureau of Industry Economics (BIE, 1995:ix$\mathrm{x}$ ) asserts that concern about non-APEC economies free-riding on APEC's plans to liberalise trade

has no merit from an economic viewpoint. Import barriers typically impose a greater cost on the country using them than they do to other countries. Hence, a nation is doing itself an even greater economic favour than it is doing for its trading partners by removing its trade barriers.

Similarly, Elek (1995:6) claims that APEC does not need 'legalistic texts' or enforcement mechanisms.

Such arguments for downplaying the free-rider problem ignore two distinctions that are crucial to the positive theory of intennational trade policy. The first is the distinction between the weights implicitly assigned by the political process to the gains and losses of the groups affected by protection, and the weights assigned to these gains and losses in the standard economists' argument for free trade, which assumes that a dollar of gain or loss to any one citizen has the same social value as a dollar of gain or loss to any other citizen. In contrast, a government wanting to retain office will put more weight on a dollar of gain or loss to a group concentrated in marginal electorates than on a dollar of gain or loss to a widely dispersed group, or to one concentrated in safe electorates. Only by neglecting this distinction can one reach the naive conclusion that govemments will not try to free-ride on trade liberalisation agreements, merely because they would not do so if they always followed the advice of economists.

The second crucial distinction is that between outcomes under cooperative arrangements and those under non-cooperative ones. To justify spending any resources

4 This definition of regionalism is taken from Bhagwati (1993); the definition of openness is from Elek (1995). 
on setting up a multilateral-trade policy institution, such as APEC, it is necessary to assume that these outcomes would not be the same, since otherwise there would be nothing useful for the institution to do. But if the non-cooperative and cooperative outcomes differ, mechanisms must be designed for stopping attempts by governments to adopt non-cooperative strategies, despite having promised to adopt cooperative ones. Since free-riding means following a non-cooperative strategy when others are following cooperative strategies. and since the basic purpose of a multilateral agreement is to ensure that governments adopt cooperative rather than non-cooperative strategies, it clearly makes little sense to propose a multilateral institution while ignoring or dismissing the importance of free-riding.

One source of the belief that enforcement of globalism by APEC will not face serious difficulties is a series of articles by Drysdale and Garnaut (1993, 1994a, 1994b) and Garnaut (1994). These authors set out an optimistic view of trade negotiations, which they call the 'prisoners' delight'. Free-riding does not occur in this model because the pay-offs that determine tariff policy are consistent with those which would be obtained if govenments always acted on the advice of free-trade economists. The differences between this model and the traditional (and, I believe, more relevant 'prisoners' dilemma' model) can be illustrated by Table 1, which shows the pay-offs to two governments which result from the tarifl settings of each. Although the table is only illustrative, it is argued here that it captures the stylised features of actual trade negotiations.

'The prisoners' dilemma can be illustrated by deleting the row and column corresponding to high tariffs, so that the table collapses to the four cells in the top left corner. In the absence of some way of enforcing a cooperative agreement, the home government's best strategy, for either tarifl setting by the foreign government, is to set a moderate tariff rather than a low one. Similarly, for either tariff setting by the home government, the best strategy for the foreign govenument is to set a moderate tariff rather than a low one. In the absence of an enforceable cooperative agreement, both governments would therefore set moderate tariffs, and end up worse off than if they had both set low tariffs. It would therefore be in the interest of both to establish an institution, such as the WTO, through which they could commit themselves to adopt low tariffs, in exchange for an agreement that the other government would also set low tariffs.

\footnotetext{
${ }^{5}$ If there were several possible non-cooperative equilibia, and if one of them coincided with the cooperative equilibrium, even a purely indicative trade agreement might play a useful coordinating role, since governments would have no incentive to free-ride in this situation. If this theoretical possibility were of practical relevance in selling tarill and non-taill barriers, the experience of negotiating and enforcing multilateral trade agreements would have involved much less disagreement than it actually has. Coordination problems are relevant in the administration of salety standards and customs procedures. These issues are discussed in the section on administrative harmonisation. 6

The models of trade negotiations set out in this section were originally illustrated by a story about two hypothetical prisoners, each faced with a choice between (a) denying a crime and (b) confessing it and implicating the other in recurn for a reduced sentence.
} 
Table 1

\section{Pay-offs to the home and foreign governments under different trade policies}

\begin{tabular}{|l|l|c|c|c|}
\hline \multicolumn{2}{|c|}{} & \multicolumn{3}{c|}{ Foreign government's tariffs } \\
\cline { 3 - 5 } \multicolumn{2}{|c|}{} & Low & Moderate & High \\
\hline \multirow{2}{*}{$\begin{array}{l}\text { Home } \\
\text { government's } \\
\text { tariffs }\end{array}$} & Low & 16,16 & 6,20 & 4,16 \\
\cline { 2 - 5 } & Moderate & 20,6 & 10,10 & 5,5 \\
\cline { 2 - 5 } & High & 16,4 & 5,5 & 0,0 \\
\hline
\end{tabular}

Note: the first number in each cell is the pay-off to the 'home' govemment, while the second is the pay-off to the 'representative foreign' govemment.

The prisoners' delight model can also be illustrated as a special case of Table 1 by deleting the row and column corresponding to low tariffs, leaving the four cells in the bottom right corner. In these four cells, it is assumed that each government gains by setting a moderate tariff rather than a high one, whatever the tariff set by the other. This is consistent with the view that almost everyone loses from the setting of high tariffs. In choosing between moderate and high tariffs, the dominant strategy for each government is therefore to set a moderate tariff, and the result is that both achieve the best of the four available outcomes in the truncated table. The happy result that neither government has an incentive to free-ride on the other arises only because the cooperative and non-cooperative outcomes are identical. This in turn implies that a cooperative agreement between the two governments would serve no useful purpose.

Table 1 illustrates a general proposition: the prisoners' delight case is irrelevant both in non-cooperative situations and in the design of institutions for achieving international cooperation. Even if there are some tariff ranges over which the prisoners' delight case holds, these ranges are irrelevant. This can be seen as follows. If the whole range of tariffs in Table 1 is available, low tariffs are chosen if countries can enforce cooperation, whereas moderate tariffs are chosen in the absence of enforceable cooperation; but these are exactly the same outcomes as those which result when the prisoners' delight part of the table is deleted. The reason for the irrelevance of the prisoners' delight case in trade negotiations is simple: cooperative agreements can never be needed to ensure trade liberalisations across tariff ranges over which it is in a government's self-interest to liberalise, regardless of what other governments may do.

\section{Experience under GATT: Free-riding and Unilateral Trade Liberalisations}

GATT's history was largely one of difficult negotiations, involving concessions, followed by attempts by many countries to find loopholes by which to avoid making these concessions, leading eventually to further negotiations to try to close the loopholes which had been created. Examples of such loopholes include: the use of waiv-

${ }^{7}$ See Snape (1985), particularly pages 48. 
ers to avoid the application of GATT rules to agricultural protection; the use of quotas under the multi-fibre agreement; the negotiation of 'voluntary' export restrictions; the use of quarantine restrictions for protective purposes; and the sometimes illegitimate use of anti-dumping measures. These creative, but non-cooperative, attempts at avoiding commitments to liberalise trade necessitated a cooperative attempt, during the Uruguay Round, to strengthen the mechanisms for detecting, deterring, and otherwise limiting attempts to renege on cooperative agreements. The kinds of mechanisms needed to enforce even partial compliance with commitments to liberalise trade are indicated by the hundreds of pages, megabytes of schedules, and seven years of negotiations involved in finalising the Uruguay Round.

The GATT experience, summarised above, is entirely consistent with the prediction of the prisoners' dilemma model that countries lave incentives to look for ways of reneging even on nominally binding agreements. However, to account for the unilateral trade liberalisations in excess of GATT requirements which have also occurred, particularly in the last ten to 15 years, it is necessary to assume that the countries involved have increased their estimates of the benefits obtainable from trade liberalisation. Such an assumption is very plausible, since it is merely one example of a worldwide growth in scepticism about the desirability of government attempts to regulate markets. The economic successes of the outward-oriented East Asian economies have been both cause and consequence of the worldwide changes in attitudes towards restrictions on international trade.

The prisoners' dilemma model predicts that if there is an increase in the perceived benefits from trade liberalisation, and if cooperative trade negotiations, like the Uruguay Round, involve delays and take place only infrequently, then the countries that liberalise unilaterally will be the sinall ones. This is because, the smaller the country, the smaller the gap between the tariffs which its government would set under cooperative and non-cooperative arrangements; and, therefore, the smaller the change in the perceived benefits from trade liberalisation needed to make the tariff which would be optimal under non-cooperative arrangements smaller than the tariff which was formerly optimal under cooperative arrangements. In conformity with this prediction, most unilateral liberalisations in the last ten to 15 years have indeed been undertaken by small countries.

\section{Administrative Harmonisation}

The use of country-specific procedures for administering trade and investment regulations can itself be a form of non-tariff barrier (NTB). For example, the US has complained that Japan's use of Japanese rather than international administrative procedures of Japanese quality and safety standards is a barrier against US exports. The harmonisation of administrative procedures within a region is therefore a way of reducing NTBs on intra-regional trade without reducing NTBs on inter-regional trade.

\footnotetext{
${ }^{8}$ If all tariffs are set on MFN principles, and if one country is too small to aflect other countries, its tariffs will be ignored by them. The outromes for the small country and for all others will then be the same, whether or not it takes part in cooperative aurangements with them.
} 
Just as reducing tariffs only on intra-regional trade would have trade-diverting effects as well as trade-creating effects, so too regional harmonisation would divert trade as well as create it. However, the fact that the trade-diverting effects of harmonisation are less obvious than those of regional tariff preferences has helped to generate many proposals for APEC-wide harmonisation of administrative regulations on trade and investment. ${ }^{9}$ The possible areas for harmonisation that have been suggested include: the treatment of foreign investment, including taxation and dispute-resolution procedures; environmental regulations; customs procedures and documents; product safety and quality standards; labelling laws; and competition policies.

However, even in these areas, the scope for coordination among APEC countries which is both mutually beneficial and genuinely rational is limited by two facts. First, since institutions for harmonising trade and investment procedures on a global basis already exist, it could well be counter-productive to set up competing regional harmonisation procedures. Second, the scope for mutually beneficial harmonisation is probably far smaller than it might appear at first glance: the costs to individual countries of harmonising particular policies may often be very large, since harmonisation involves changing and relearning complex administrative procedures. If these costs were not substantial, all coordination problems would have been solved long ago. The abundance of proposals for regional harmonisation is matched by a scarcity of detailed analysis of them. For example, all the works listed in footnote 9 recommend harmonisation of customs procedures, but none explains how APEC will improve on, or even how it will relate to, global attempts at harmonisation. If the example of customs procedures is typical, it appears that regional harmonisation will not involve the setting up of regional standards to compete with globally agreed standards: rather, APEC will try to influence the setting of new global conventions, and some members will increase their efforts to comply with global harmonisation plans. ${ }^{10}$ This may well be useful, but is unlikely to be of great importance, and contains only minor elements of regionalism.

Since it would be prohibitively expensive to amend the vast array of existing statute and case law in member countries, it would be unrealistic to expect real harmonisation of competition policies on an APEC-wide basis. Similarly, the cost of amending existing investment laws and regulations is also one of the reasons why APEC's 1994 investment code is empty. Not only is this code non-binding, it also contains numerous escape clauses, of which the most transparent is the provision that foreign investors can be denied national treatment with exceptions as provided for in domestic laws, regulations and policies.

\footnotetext{
9 See, for example, EPG Report (1994:10-17, 32-3); EJek (1992); BIE (1995:29-30); Yamazawa (1993). 10 APEC and the World Customs Organisation lave each set up working groups to review the out-ofdate guidelines for global customs harmonisation under the 1973 Kyoto Convention, and to make recommendations for a revised convention. When the reviews have been completed, and when a new convention has been agreed to, the individual country administrations will begin the process of accession to, and implementation of, the revised procedures. This will be a very slow process: merely finalising the preamble of the new convention is expected to take about three years.
} 
Agreements to ensure the national treatment of foreign investors clearly involves much more than mere harmonisation of administrative procedures. In my view, investment liberalisation can probably be done best on a plurilateral rather than a fully MFN basis, by drawing up an investment code whose main provision would be that countries which signed the code would guarantee to grant national treatment, including right of establishment, to investors from all other countries that had signed the code. This element of reciprocity would limit the scope for free-riding. The arrangement should be negotiated and administered through the WTO, since no useful purpose would be served by restricting it to APEC members.

\section{Concerted Unilateral Liberalisation}

It has been widely reported that at the APEC leaders' meeting in Osaka in November 1995, the Japanese govenument will propose that each APEC government should set the rate at which it plans to fulfil its commitments under the Bogor Declaration, and that a review mechanism should be used to monitor each country's progress (The Australian, 23 March 1995). Under this proposal, APEC liberalisations would be available to all members of the WTO on a fully MFN basis. An indication of the weakness of the proposal is that a new piece of APEC double-talk, 'concerted unilateral liberalisation', has been invented to describe it.

It is often argued that one of the useful purposes served by the WTO, and before it by GATT, is to allow a government which wishes to pursue trade liberalisation to deflect opposition from previously protected domestic interest groups by pointing to its external commitments. Since the force of this argument is proportional to the severity of the sanctions which a country would incur by breaking its commitments, it has little force as a defence of concerted unilateral liberalisation. This is because of two crucial differences between WTO agreements and APEC agreements under globalism. First, the former are binding commitments, whereas the latter are not. Second, a government cannot break its commitments to the WTO with complete impunity, because of the WTO's detailed rules and sanctions; in contrast, under globalism, even expulsion from APEC would have no adverse elfects on the tariffs and NTBs faced by a country's exports. Under globalism, the only sanction available to APEC would be moral suasion. Since recent history abounds with examples of promises to domestic groups which governments liave broken, there is little basis for confidence in non-binding commitments to foreigners. The Australian government endorsed the utopian goal of complete free trade by 2010 less than a month after it had reneged on an apparently binding commitment to open its aviation market to competition from New Zealand the following week.

\section{Conclusion}

APEC's membership is now so large and disparate that it would probably be impossible to transform it into an FTA. Yet Australia should not take the lead in closing off regionalist options, since it could well benefit from even a limited extension of regional free trade. APEC may pretend to aclopt globalism, but, with moral suasion as its only 
weapon, it will have negligible effects on trade liberalisation. Besides, any trade liberalisation that can be effected on a fully MFN basis by APEC can be done better through the WTO. "I do not believe that the Bogor Declaration will ever be unilaterally implemented on a fully MFN basis, because it would be like a GATT round in which Europe, and any APEC countries which chose to free-ride on the others, would receive all the benefits of whatever liberalisations were made without being required to make any politically painful concessions themselves; meanwhile, those APEC governments that kept to the Bogor Declaration would have to concede very much more than they conceded in the Uruguay Round.

Given the political capital that has been invested in APEC, attempts will be made to claim major achievements on its behalf, by attributing to it all instances of regional cooperation and unilateral trade liberalisation involving APEC countries. Defenders of APEC already point to its investment code as an example of cooperation in reducing barriers between APEC economies, and to Indonesia's May 1995 deregulation package as an example of a trade reform brought about by the Bogor Declaration. The weakness of these claims is obvious: the investment code is both non-binding and full of loopholes; and deregulation packages have been a roughly annual event in Indonesia since the mid-1980s. The imagination reels at the thought of what would have been claimed on APEC's behalf if it had been set up before the widespread process of unilateral liberalisation in the Asia-Pacific region got under way.

Since the governments which have invested political capital in it need something to point to when challenged by sceptics, APEC probably will have some small liberalising effects on trade policy in the short run, even though these efforts are likely to involve mainly the timing and packaging of reforms and to fall far short both of the goals of the Bogor Declaration and of what is claimed on APEC's behalf. In drawing up a balance sheet for APEC, three costs must be set against any minor short-term benefits. First, the making of unrealistic promises has its own costs, one of which is the risk that APEC may eventually discredit more serious attempts to liberalise trade by failing to fulfil its promises. Second, APEC has probably already delayed multilateral trade negotiations: the non-APEC members of the WTO have little incentive to begin negotiating reciprocal trade liberalisation as long as APEC countries continue to make promises among themselves to concede unilaterally all that the others might demand in a new WTO round. Third, there is the cost of administering APEC. If it does eventually subside into a regional version of the OECD, it would not be the first time that the main legacy of a political gimmick has been a new bureaucracy.

\footnotetext{
"An overview of the implications for tarill policy of possible retaliation by other counties is given by Corden (1974:172-6).
} 


\section{References}

APEC Ministerial Meeting (1994), 'Economic Leaders' Declaration of Common Resolve', Bogor.

Bhagwati, J. (1993), 'Regionalism and Multilateralism: An Oveıvicw', in J. de Melo \& A. Panagariya (eds), New Dimensions in Regional Integration, Cambridge University Press, Cambridge.

Bureau of Industry Economics (BIE) (1995), Potestial Gains to Australia from APEC: Open Regionalism and the Bogor Declaration, AGPS, Canbena (Occasional Paper 29).

Corden, W. (1974), Trade Policy and Economic Welfiuc, Clarendon Press, Oxford.

Drysdale, P. \& R. Ganıut (1993a), 'The Pacilic: an Application of a General Theory of Economic Integration', in C. Bengsten \& M. Noland (eds), Pacific Dyuamism and the Intenuational Economic System, Institute for International Economics, Washington DC.

- (1993b), 'NAFTA and the Asia-Pacilic Region: Suratcgic Responses', in R. Cushing et al. (eds), The Challenge of NAFTA, Lyndon B. Jolunson School of Public Allairs, Austin.

- (1994), 'Principles of Pacific Economic Integation', in R. Ganıut \& P. Drysdale (eds), Asja-Pacific Regionalism: Readings in Intenzational Exonomic Rehations, Harper Educational Publishers, Sydney.

Elek, A. (1992), 'Pacific Economic Cooperation: Policy Choices for the 1990s', Asiur-Pacific Economic Literature 6(1): 1-15.

- (1995), 'APEC Beyond Bogor: An Open Economic Association in the Asia-Pacilic Region', AsianPacific Economic Literature 9(1): 1-16.

Eminent Persons Group (EPG) (1994), Aclieving the APEC Vision: Free and Open Trade in the AsiaPacific, Asia-Pacific Economic Cooperation, Singapore.

Gannaut, R. (1994), 'Open Regionalism: Its Analytic Basis and Relevance to the Intemational System', Jounal of Asian Economics 5(2): 273-90.

Snape, R. (1985), 'International Trade - What Rules?', Mimeo of Address to the Mont Pelerin Society, Sydney.

Yamazawa, I. (1993), 'Fast Asian Dynamism aurd Pacilic Cooperation', Policy 9(2): 2-5.

I wish to thank Anne Daly, Ross McLeod, Ray Trewin, and the referees for their helpful comments. 


\section{CLARIFICATION}

A Note by James Cox titled How Much Spending? The EPAC Survey of Public Expenditure Preferences in Australia was published in Agenda, volume 2, number 2, 1995. The authors of the EPAC report Public Expenditure in Australia wish to make it clear that the survey of public expenditure preferences was not commissioned or funded by EPAC but was an independent study conducted by David Throsby and Glenn Withers under Australian Research Council funding. 